\title{
The Tax Knowledge of South African Trainee Accountants: A Survey of the Perceptions of Training Officers in Public Practice
}

\author{
STEPHEN COETZEE and RUANDA OBERHOLZER
}

University of Pretoria, South Africa

\begin{abstract}
This empirically-based, exploratory study outlines the framework of chartered accountants' tax education and training in South Africa and focuses on training officers' perceptions of the existing tax knowledge of trainee accountants when entering into a training contract after completing their university qualification. The study identified the respondents' satisfaction with the performance by 'entry-level' trainee accountants of their duties. The results indicated that, although the educational background of trainee accountants was for the most part adequate, these trainee accountants were not sufficiently able to perform their duties when entering into training. The implication of this study is that the syllabus setters and educators should review the practicality of the current tax syllabi's content for the education and training of aspirant chartered accountants in South Africa.

Keywords: Tax education; tax training; tax knowledge; training officers' perceptions; training in public practice
\end{abstract}

\section{Introduction}

The education and training programmes of many professions, including the chartered accountancy profession in South Africa, place their emphasis on successful completion of a written qualifying examination in order to enter the profession. Botha (2001, p. 42) suggested that these examinations are not necessarily reflective of a competent professional, as written examinations primarily tests knowledge, and are not necessarily indicative of a person's ability in the practice environment.

In South Africa, the South African Institute of Chartered Accountants (SAICA) is responsible for developing the syllabus that must be completed by a trainee chartered accountant, at a SAICAaccredited university, prior to writing the final qualifying examinations administered by SAICA and the Independent Regulatory Board for Auditors (IRBA). The syllabus covers four major disciplines, namely, financial accounting (40\%), auditing (20\%), financial management (20\%) and taxation (20\%). The final qualifying examinations are written, after completion of the fulltime academic programme at a university, during the three years of practical training in the training environment. (See Figure 1.) 


\section{Three years full-time B Com accounting degree, or equivalent, at a tertiary education institution.}

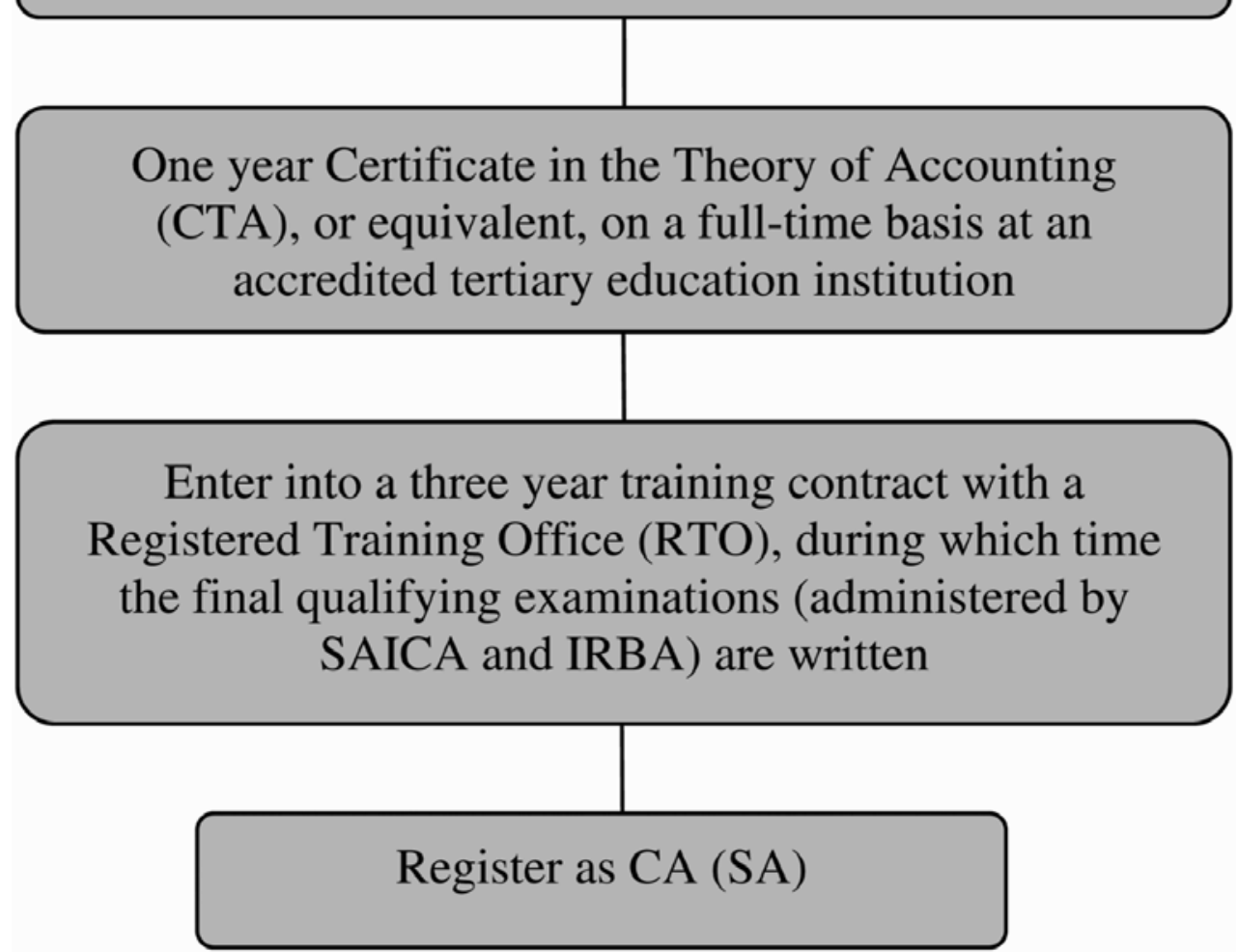

Figure 1. Qualification route as a CA (SA) in public practice on a full-time academic programme

Alternatively, students may undertake their academic programme on a part-time basis through a distance education institution and, at the same time, complete their practical training. Under these circumstances the training programme is extended to five years. Remission will, however, be granted on attainment of a relevant degree.

To the authors' knowledge no formal research has been performed in South Africa of the tax knowledge of trainee chartered accountants entering the training environment immediately after completing their academic programme at university. Similar studies have been performed internationally and this area of research was found to be of interest, inter alia, to practitioners, academics, students and curriculum developers. Schwartz and Stout (1987) conducted a survey in the USA in an attempt to identify the practitioners' opinions of the accounting graduates' preparedness for practice and suggested that these graduates were marginally prepared at best. In 1999-2000, the tax education committee of the American Institute of Certified Public Accountants (AICPA) conducted a survey amongst practitioners into the current state of affairs in the tax profession in the USA. Schnee (1999) commented on the results of this survey by the AICPA and suggested that a number of practitioners were of the opinion that the educational model in the USA had become obsolete and universities needed to re-evaluate their curricula. The commentary and studies performed internationally are useful. However, these studies focused on the public practice environment in a developed country and not in a developing country, such as South Africa. 
Training officers are appointed by SAICA to facilitate the professional training programmes in firms throughout South Africa. The training officer must be a member of SAICA, who holds a position of sufficient seniority in a firm to influence the planning and implementation of trainees' work experience and study programmes (SAICA, 2006a). The training officers have the responsibility of ensuring that the trainee accountants receive the appropriate training in accordance with the SAICA requirements for the training programmes. They should, therefore, be in an ideal position from which to express an opinion on the subject matter of this study.

Historically, South Africa has followed an unstructured approach to the qualification of tax advisors and practitioners. It is, currently, not a prerequisite for a tax practitioner in South Africa to be a member of SAICA or any other professional or controlling body. Recently, there has been an increased focus on tax practitioner regulation and qualification. The South African Revenue Services (SARS) issued a discussion document on the formalisation of tax practitioner regulation and the establishment of one controlling body for tax advisors (SARS, 2002, p. 14). This regulatory process is, however, in its infancy and has not yet been completed. Conversely, the chartered accountant designation is well established and is held in high esteem in South Africa (SAICA, 2007). Consequently, several tax specialists traditionally qualify as chartered accountants prior to specialising in tax. In addition, the majority of chartered accounting firms offer tax advisory services.

\section{Research Objective}

This study initially provided a description of the current chartered accountant training environment and training programme in public practice in South Africa, followed by a discussion of tax knowledge. The empirical study then attempted to identify the perceptions of training officers in public practice regarding the existing tax knowledge of trainee accountants when entering a SAICA-accredited training contract, immediately after completing the full-time academic programme at a SAICA-accredited university. In addition, the study attempted to identify the training officers' level of satisfaction with the performance of their duties, by these entry-level trainee accountants, based on the trainee accountants' existing tax knowledge gained at a SAICA-accredited university. It is not the purpose of this exploratory study to generalize the conclusions reached to all training officers. This study attempted to provide an indication of the way forward for tax education in South Africa and to provide SAICA with insights into the current market expectations of the taxation education programme.

\section{Background and Literature Review}

In order to obtain a background for the study, a review was made of certain important terms contained in the study, namely the training environment, the training programme and tax knowledge. 


\section{The Training Environment}

A trainee accountant is required to complete a period of training before qualifying as a chartered accountant in South Africa. For this purpose SAICA identifies registered training offices (RTO) at which training can be undertaken. To obtain SAICA recognition for training purposes a firm must have the ability to deliver an appropriate breadth, depth and quality of training in an environment conducive to the training of chartered accountants. To achieve a training environment that is conducive, a firm should have a formal policy defined to provide for 'on the job' training, an adequate system to monitor the academic progress of trainees, and provide appropriate counselling. SAICA has indicated that no firm will be excluded from being a training office based on size. The firm should, however, be in the position to facilitate work experience of adequate breadth and depth to provide sufficient opportunity for personal and professional development, and facilitate sufficient experience of the ethical dimension of the profession (SAICA, 2006a). Coetzee (2006, p. 42), chairman of the SAICA trainee requirement committee, stated that the SAICA requirements for a training environment enable all training offices to provide consistent quality training in a formally structured and monitored way. The training environment should provide sufficient monitoring and supervision for the training programme. A training officer, who is appropriately qualified and knowledgeable, is vital in this regard and should be appointed to coordinate the training programme and act as mentor (SAICA, 2006a).

\section{The Training Programme}

The duties of a chartered accountant in public practice include, inter alia, advising his/her clients on how to legally minimize their tax liabilities through efficient tax planning, submitting tax returns, resolving tax problems, advising on tax implications, advising on litigation matters, and generally aiding clients with their personal financial affairs (SAICA, 2006b). Training in Public Practice (TIPP) represents the traditional audit route of qualifying as a chartered accountant. This route is a prerequisite for registration as a Registered Auditor (RA) with the Independent Regulatory Board for Auditors (IRBA).

Training is undertaken in accountancy firms broadly classified into three categories, namely small, medium and large firms.

Small firms are generally community-based and have a very personal approach towards clients. These clients generally consist of private individuals, entrepreneurs, local retailers and manufacturers, and small or medium-sized companies or close corporations. The firm generally fulfils the role of financial director to many of these clients, who are too small to justify the cost of a full-time financial director in their employ. Trainee accountants are afforded the opportunity of experiencing the business as a whole and making key contributions to these clients. Tax planning and administration for their clients plays a significant role in the functioning of these small firms (SAICA, 2006c).

Medium firms tend to serve a very similar client profile to those of small firms. However, they tend to have a network of national offices and are as such in a better position to serve larger clients with national exposure. As with a small firm, the clients cover a diverse range of product and service sectors (SAICA, 2006c). 
Large firms generally comprised of the so-called 'Big 4' auditing firms, namely Deloitte, Ernst and Young, KPMG and PriceWaterhouseCoopers. These 'Big 4' firms were identified based on a survey of fee income by the International Accounting Bulletin (Dayasena, 2003, p. 12). These firms offer a team-oriented approach that is often specialized. Trainee accountants are exposed to some of the world's most prestigious companies, across a vast range of industries (SAICA, 2006c).

\section{Tax Knowledge}

SAICA acknowledges that, in order to meet the increasing challenges of an increasingly complex economic environment and its associated transactions, it must be ensured that trainee accountants achieve a high level of competence. SAICA has indicated that trainee accountants obtain competence through, not only practical experience in the training environment, but also through education (SAICA, 2003).

Botha and de Jager (2001, p. 31) stated that:

Competence requirements for the accounting profession must focus on all three the essential elements of professional competence, namely knowledge, skills and professional attitudes. (Emphasis in original.)

A person acquires knowledge when information from a variety of sources is internalized through thinking, learning and experience. Knowledge represents the 'knowing that' and the 'knowing how' in respect of a specific subject matter and is separately identifiable from skills (Botha and De Jager, 2001, p. 34). Skills refers to the 'being able to' in a practical situation and the 'knowing how to' is a procedural knowledge acquired in the academic environment (Botha and de Jager, 2001, p. 35).

The focus of this study is on entry-level trainee accountants, and therefore, is on the knowledge, 'knowing that' and 'knowing how', gained by trainee accountants in an academic environment before entering the training environment to obtain the skill of 'being able to' in practice.

All accredited universities must follow the tax syllabus prescribed by SAICA when educating chartered accounting students, prior to these students entering the training environment. The aim of this tax syllabus is to ensure that a chartered accountant is able to interpret and apply tax legislation, is able to recognize applications of tax legislation, and evaluate current applications of tax legislation (SAICA, 2003, p. 65). To develop the tax curriculum SAICA established a syllabus committee comprising an education committee member (chairman), targeted members from public practice and commerce and industry and academics nominated by accredited educational institutions. The committee develops and revises the syllabus after consultation with overseas institutes of chartered accountants and consultation with education institutions in South Africa (SAICA, 2003, p. 10).

While responsible for the tax syllabus, SAICA is not responsible for providing courses or educational material (SAICA, 2006d). SAICA is, however, responsible for the accreditation and monitoring of the Certificate in Theory of Accounting (CTA) programmes (including the tax 
component thereof) at universities and ensuring that the outcomes of the syllabus are being achieved. The monitoring process involves regular and ongoing institutional visits, review of courses, review of assessment criteria, and monitoring of students' performance in assessments $\left(\right.$ SAICA, 2006 $\left.{ }^{\mathrm{d}}\right)$. Accreditation is specific to the post-graduate CTA and Niewoudt and Wilcocks (2005) acknowledged that the curriculum set by SAICA has in fact become that for the honours degree awarded by the accredited universities. It is, however, submitted that the nature of this accreditation encourages the universities to base the development of their undergraduate courses on the SAICA syllabus as well. Due to the emphasis placed on the SAICA syllabus the vast majority of educators involved in the tax education of future chartered accountants are themselves chartered accountants. A recent survey of accounting academics in South Africa by Niewoudt and Wilcocks (2005, p. 57) suggested that 70\% of the accounting academics (including those specialising in taxation) are chartered accountants, yet only $49 \%$ of the accounting academics hold a masters or a doctoral degree.

Although the SAICA tax syllabus and training programmes are the immediate background to this study, acknowledgement should be made of the broader educational environment in which education and training programmes in South Africa operate, namely the National Qualifying Framework (NQF). The post apartheid government in South Africa has made the acquisition of skills by entrants to the labour market and those previously disadvantaged persons a priority. Key to this process has been the implementation of a new NQF in South Africa since the mid1990s. The aim of the NQF is to encourage an integrated approach to education and training which rejects the rigid divisions between academic and training and between knowledge and skill across all areas of education (Dept of Education, 1995, emphasis added).

The NQF is quite different from other international frameworks in that it is based on a unit standard methodology and attempts to regulate all education and training qualifications in South Africa. The NQF in New Zealand shares the unit standard approach. However, it differs in that its framework is voluntary and does not include higher education. The NQF in Australia is not unit standard based and instead recognizes different types of learning on an institutional basis. This is similar to the Scottish system, which aims to differentiate qualifications, rather than shape the curriculum from the ground up, as is the case in South Africa (Ensor, 2003).

Ensor (2003) acknowledged that the aims of the NQF have caused significant friction between universities and the state. One reason for this, inter alia, is the existence of two types of degree programmes in higher education: 'those that are general and formative and those that are career or occupationally focused' (Ensor, 2003, p. 339). While the NQF of other countries may acknowledge this difference, the NQF in South Africa has been geared specifically towards vocational training.

\section{International Literature}

Initial warnings that tax education needs to be reviewed were issued when Gray (1965) conducted a survey of tax professors concerning the courses they were teaching and the content thereof. A majority of the professors indicated that their courses were not primarily 
computational and that the focus of the undergraduate tax courses should be 'why' rather than 'how'. Fogg and Campbell (1982) subsequently suggested that the content of tax courses in the USA had not changed significantly and again surveyed tax educators on what was being taught. The authors concluded that significant changes were necessary in order to meet the everchanging demands of practitioners.

Schwartz and Stout (1987) conducted a comparative study of practitioners and educators to identify their opinions of accounting graduates' preparedness for practice. They concluded that practitioners believe that accounting graduates are marginally prepared, at best, to meet their expectations in practice. The practitioners considered more practical and computational methods of education to be more important than what the educators did. The educators surveyed held a more inflated opinion of the preparedness of accounting graduates. It was concluded that more effective levels of communication between the practitioners and educators was vital. Consideration by both parties of the others' opinion was necessary.

Flesher and Rescho (1986) surveyed tax professionals involved in education and practice and Boley and Wilkie (1986) surveyed partners and sole practitioners in the USA, both in an attempt to identify a framework of generally accepted tax concepts or 'common body of tax knowledge'. These authors suggested that highly technical concepts, of a specialized nature, should not be included in a tax programme. Boley and Wilkie (1986, p. 95) concluded that consensus on curriculum content was found to vary with firm size. A subsequent survey by Stara, Shoemaker and Brown (1991) of practitioners' opinions on the tax programmes again suggested that large firms and small firms held differing opinions on curriculum content. Larger firms indicated a greater preference for corporate tax and tax research, whilst the smaller firms concentrated on individual tax. A survey of practitioners' opinions of tax education in the USA conducted by Schnee (1999, p. 540) again suggested that the educational model was obsolete and universities needed to re-evaluate their curricula. That author, however, cautioned universities to be careful before reducing technical course content.

The AICPA tax education committee surveyed practitioners to determine their recommendations on a model tax curriculum developed. Rubin (1999, p. 808) commented that the results of this survey suggested that the practitioners encouraged the coverage of all technical skills for both individual and business entities. Oppenheimer's (1997, p. 322) commentary on the model tax curriculum concluded that tax curricula had not changed sufficiently with the times. The focus of tax education was still on memorisation of tax rules and allowance had not been adequately made for nurturing the ability to communicate the knowledge of these rules effectively using the variety of technological means available. In a further commentary on the AICPA model tax curriculum, O'Neil (1999, p. 600) suggested that, in order for tax education to meet the needs of the accounting profession, it must be continuously updated and be relevant to accounting practice. This author suggested that the objective of accounting educators should be the conversion of students to practitioners who can be 'trusted advisors to their clients'.

Although the vast majority of research has been conducted in the USA the problem is international. Studies conducted in the UK and New Zealand by Miller and Woods (2000) and Tan and Veal (2005), respectively, have also concluded educators' and practitioners' opinions of tax education varied. Miller and Woods (2000) commented that these differing perceptions of 
accounting graduates' abilities and preparedness for practice may be due to universities not succeeding with the students' transferable ability from the academic environment to the practice environment. Tan and Veal (2005) suggested that the practitioners in New Zealand required a greater conceptual understanding of tax and coverage of a wider range of tax topics than the educators. These findings are in contrast with the studies in the USA and UK, which placed more emphasis on computation. The emphasis on computational ability in the UK was also highlighted in a survey of UK undergraduate tax courses by Craner and Lymer (1999). Their study concentrated on the relationship between the characteristics of tax courses in the UK and not the tax practitioners' perceptions. Despite the fact that practitioners were not considered in their study, Craner and Lymer (1999) concluded that the computational nature of the UK courses may be due to the professional tax practice backgrounds of the educators involved in these courses.

International research, therefore, generally suggests that practitioners require graduates who can think on their feet yet also be well grounded in the theory and its application. Mulder (2000, p. 1) acknowledged that the accounting educator's task of achieving this level of critical and independent thinking in their students is indeed a challenging one and the goals of practitioners will only be met if educators can devise and implement appropriate programmes that teach students how to use their critical faculties. Mulder (2000, p. 1) conceded that developing and implementing such programmes is far more challenging than a mere transfer of theoretical knowledge.

In response to the research conducted in the USA, the teaching methods in taxation appear to be departing from a rule-driven approach to a more abstract approach, considering both the memorisation of rules and the ability to apply these rules through varying teaching methods, cases and testing techniques (Hite and Hasseldine, 2001).

\section{Method}

This empirical research project was an exploratory descriptive study of the perceptions of training officers in public practice of the tax education of entry-level trainee accountants in South Africa based on communicative methods of data collection via a structured, self-administered email questionnaire. Due to the absence of reported research on tax education and training in South Africa, the framework for this empirical study was provided by tax educational issues identified in foreign literature, supplemented by the study of South African literature on accounting education and training in general. The study was ex post facto to minimize the effect of any bias on the part of the researcher. The study was cross-sectional in order to capture the opinions of the respondents at a specific point in time.

\section{Target Population}

Due to the exploratory nature of this research the target population for this study was limited to the training officers in public practice in Pretoria, South Africa, as registered with SAICA on 19 May 2006. The capital of South Africa, Pretoria, has a balanced and diverse industrial economy (Tshwane, 2007). All 'Big 4' firms have representation in the city along with a 
significant number of small and medium firms. Of the approximately 800 training offices registered with SAICA, 119 (15\%) of these are located in Pretoria, 149 (18\%) in Johannesburg, 140 (17\%) in Cape Town and 64 (8\%) in Durban. As the percentage of training officers registered with SAICA in Pretoria compares well with the other major cities in South Africa it is submitted that the selected area of Pretoria is suitable for this study.

\section{Sampling Method and Size}

A list of the 119 training offices (p) in public practice, registered on 19 May 2006, in Pretoria, was obtained from SAICA. A randomized sample was extracted based on a random computer selection. Those firms involved in TIPP consist of small, medium and large firms, including the 'Big 4' auditing firms. The randomized sample selection technique was modified to ensure that all 'Big 4' firms were circularized. The sample size was calculated in accordance with the formula $(\sqrt{p / 20} \times 20$ ) devised by Stroker (1981) and resulted in a sample of 48 training firms.

\section{Data Collection}

Validity and reliability are issues in any social research (Mouton, 2001). To ensure content validity the study design was preceded by an extensive review of literature. The data collection method was based on a survey approach as utilized by studies of a similar nature internationally. The respondents were required to complete a structured self-administered e-mailed questionnaire based, in part, on the study of Schwartz and Stout (1987). The questionnaire was, however, extensively modified in respect of the tax topics identified due to the uniqueness of tax laws in the USA and South Africa. The questionnaire primarily required the respondents to provide quantitative data. However, an opportunity was provided for additional comment by means of an open-ended question.

The questionnaire and covering letter, in electronic format, was forwarded to the respondents identified in the randomized sample selection during April 2006. This time scale allowed the respondents sufficient time to assess the January intake of new trainees' knowledge, but limited the time available in which this assessment could be influenced by skills acquired by the trainees in the practice environment. A second request was forwarded one and a half weeks after the initial distribution of the questionnaire to those respondents who had not reacted to the initial correspondence. A reminder was e-mailed to the respondents after two weeks with a final request after three weeks. The respondents were contacted by telephone prior to each e-mail distribution to request permission for distribution of the message. Subsequently telephone contact was made to confirm receipt of the e-mail and ascertain if any difficulties were being experienced with the research instrument.

\section{Pre-testing}

To supplement the review of literature and enhance content validity a pilot study was conducted by e-mailing the questionnaire to four full-time academics, with research and practice experience, as well as a practitioner, who has previous academic experience. In addition, indepth personal interviews were held with these respondents and constructive comments 
generated during the pilot study were used in finalising the questionnaire design.

\section{Response Rate}

A disappointingly low response rate of $38 \%(n=18)$ was achieved. However, the response rate was in line with similar studies conducted internationally (Refer Boley and Wilkie, 1986, 36.4\%, Flescher and Rescho, 1986, 25.8\%, Schwartz and Stout, 1987, 23\%, and Stara et al., 1991, 22.8\%). In contrast to these studies, which utilized a postal (mail) research instrument, this study utilized an electronic mail research instrument, in the format of a protected Microsoft Word document.

In a comparative study of postal mail and electronic mail as a research tool it was identified that electronic mail had a far lower response rate than traditional mail (Cooper, Blair and Triplet, 1999). These authors identified factors that are fundamental in causing this lower response rate, such as differing mail servers between organizations and other technical problems. To avoid the impact of these factors the respondents were contacted by telephone to confirm receipt of the electronic mail and, where necessary, an alternative arrangement was made, such as using an alternative e-mail address.

\section{Limitations of the Study}

This study was performed within the geographical area of Pretoria and it was thus not the purpose of the study to generalize the conclusions reached to all SAICA training officers in South Africa.

\section{Data Analysis}

The quantitative data was analysed on a conventional SPSS package Version 13 and Microsoft Excel 2003. The analysis did not involve overly complex statistical methods, as the nature of an exploratory, descriptive study does not lend itself to such an approach. The small sample size precludes statistical analysis of reliability and data analysis was confined to simple measures appropriate for rating scale data. The open-ended question was analysed using inductive logic.

\section{Results}

\section{Respondent Profile}

The first part of the questionnaire contained questions relating to the demographic profile of the respondents, all of whom are chartered accountants registered as training officers with SAICA. The respondents are primarily involved in a combination of audit, financial reporting and taxrelated matters. The respondents from the large firms are, however, primarily involved in auditing and/or financial accounting as large firms generally have specialized tax departments into which entry-level trainee accountants would not be directly admitted. The trainee accountants are exposed to tax through the attest and/or accounting functions. This should be borne in mind when interpreting the results. The respondents' level of experience with trainee 
accountants is evenly spread from very little experience (of one to five years) through to more than 21 years experience. The demographics of the respondents are illustrated in Table 1.

\begin{abstract}
Firm size
Small

Medium

Large

Number of years experience with trainees

1-5 years

6-10 years

11-20 years

21-30 years

Not answered

Primary activities

Primarily audit and/or financial reporting

Combination of audit, financial reporting and tax

\begin{tabular}{|c|c|c|c|c|c|c|}
\hline \multirow[t]{2}{*}{ Not answered } & 2 & 10 & - & - & - & -210 \\
\hline & 8 & 44 & 6 & 33 & 4 & 2318100 \\
\hline \multirow[t]{2}{*}{ Primary activities } & \multicolumn{6}{|c|}{ Small firms Medium firms Large firms Total } \\
\hline & $n$ & $\%$ & $n$ & $\%$ & $n$ & $\% \quad n \quad \%$ \\
\hline Primarily audit and/or financial reporting & - & - & 1 & 6 & 4 & $23 \quad 5 \quad 29$ \\
\hline \multirow[t]{2}{*}{ Combination of audit, financial reporting and tax } & 8 & 44 & 5 & 27 & - & -13 \\
\hline & 8 & 44 & 6 & 33 & 4 & 231810 \\
\hline
\end{tabular}

\section{Tax Knowledge of Entry-Level Trainee Accountants}

The respondents were required to indicate their perceptions of the existing tax knowledge of trainee accountants when entering a SAICA accredited training contract in respect of various tax topics identified in the questionnaire.

The current SAICA syllabus was not used as the basis of the questionnaire. This was done so as not to exclude any potential tax topic from the selection and to provide a more detailed and complete list of tax topics from which the respondents could select. The tax topics used in the questionnaire were extracted firstly by referring to the various types of taxpayers referred to in the annual tax rate announcement by the Minister of Finance; secondly with reference to the various Tax Acts; and finally with reference to the various schedules of the Income Tax Act No. 58 of 1962. Research and use of computer applications were added as identified in international research (Rubin, 1999, p. 808 and Oppenheimer, 1997).

The respondents were asked to measure their perceptions of knowledge based on a five-point Likert scale ( 1 = no knowledge through to $5=$ thorough knowledge). In an attempt to eliminate respondents providing views based on preconceptions and prejudice rather than actual experience the questions were prefaced by 'from your experience'.
\end{abstract}

\section{Table 1. Respondents' characteristics}


In order to clearly define the concept of knowledge, a definition, as derived by Botha and de Jager (2001, p. 34), was provided to the respondents. The definition states that knowledge is gained when a person internalizes information from various sources through thinking, learning and experience. Knowledge represents the 'knowing that' and the 'knowing how' in respect of identified subject matter, and is separately identifiable from the skill of 'being able to' in the practice environment. When asked to evaluate the trainee accountants' tax knowledge in general, the majority of the respondents $(61 \%, n=11)$ were of the opinion that the trainee accountants have a general tax knowledge $(M=3)$.

In order to identify specific tax topics in which the respondents perceive the trainee accountants to be most knowledgeable, a mean score was calculated for each topic (Table 2). Based on the ranking of the topics by their mean scores, from most knowledgeable $(M=5)$ to least knowledgeable $(M=1)$, it is suggested that the majority of the respondents are of the opinion that the tax knowledge of trainee accountants is leaning towards general, working or thorough knowledge $(M>2.5)$ for 15 of the 28 tax topics listed in Table 2. These results were not unexpected as 14 of these 15 topics are included in the current SAICA tax syllabus.

Table 2. Practitioners' perceptions of knowledge of trainee accountants $(n=18)$

$$
\begin{array}{cccccccc}
\text { n/a } & 1 & 2 & 3 & 4 & 5 & & \\
\text { \% } & \% & \% & \% & \% & \% & \text { SD } & \text { M }
\end{array}
$$

$1=$ No knowledge; 2 = negligible knowledge; 3 = general knowledge; $4=$ working knowledge;

5 = thorough knowledge.

$\mathrm{n} / \mathrm{a}=$ not applicable to respondent as they do not have clients to which the topic is applicable.

$\mathrm{M}=$ mean, $\mathrm{SD}=$ standard deviation.

Topics included in the SAICA syllabus

Individuals tax (excluding capital gains tax)

Secondary tax on companies (STC)

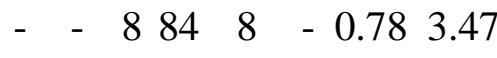

Value added tax

Company tax (excluding capital gains tax)

- $\quad-83854-0.663 .47$

Capital gains tax

Employees' tax

Fringe benefits

Computer applications (e-filing, word processor and spreadsheet, etc.)

- $8-5423150.883 .39$

- $\quad-153946-0.753 .31$

- $\quad-153946-0.753 .31$

- $\quad 86131-0.603 .23$

- $\quad 234631-0.763 .08$

$815232323 \quad 81.002 .84$

Taxation of small business corporations (excluding capital gains tax)

Provisional tax

- $8313923-0.932 .77$

Donations tax

Lump sum benefits from pension, provident and retirement annuity funds

Estate duty

Taxation of trusts (excluding capital gains tax)

- $\quad-463123-0.832 .77$

$\begin{array}{llllll}8 & -3154 & 8 & -0.62 & 2.76\end{array}$

$\begin{array}{lllllll}8 & 8 & 23 & 46 & 15 & -0.87 & 2.75\end{array}$

$\begin{array}{lllll}15 & 8 & 3131 & 15 & -0.732 .64\end{array}$

- $839468-0.782 .54$ 
General administration (returns, objections, etc.)

Taxation of employment companies

Taxation of non-resident branch

Tax planning (the structuring of, and advice on, a client's tax affairs, etc.)

International tax

Topics not included in the SAICA syllabus

Taxation of public benefit organizations (excluding capital gains tax)

Tax research (researching case law and legislation, etc.)

Taxation of farming activities

Corporate rules (unbundling, amalgamation, etc.)

Taxation of long-term insurers

Taxation of retirement funds

Transfer and stamp duties

Customs and excise duties

Taxation of mines

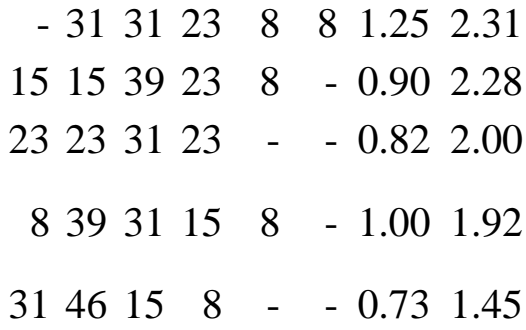

$23 \quad 8312315 \quad-0.972 .60$

$1515391515-1.032 .36$

$15154615 \quad 8 \quad-0.872 .18$

$153131 \quad 815 \quad-1.142 .09$

$\begin{array}{lllllll}39 & 31 & 8 & 15 & 8 & -1.20 & 2.01\end{array}$

$4623 \quad 823-\quad-1.002 .01$

$152346 \quad 8 \quad 8 \quad-0.892 .00$

$153131 \quad 15 \quad 8 \quad-1.002 .00$

$31548-\quad-81.331 .56$

Surprisingly, 38\% of the respondents were of the opinion that the trainee accountants have a general to working knowledge of the taxation of Public Benefit Organisations, despite this topic not being included in the current SAICA tax syllabus.

It is suggested that the trainee accountants' knowledge levels of the remaining 13 topics listed in Table 2 is leaning towards negligible to no tax knowledge $(M<2.5)$. Again these findings were largely expected as the majority of these topics are not in the current SAICA tax syllabus. Most of these topics are of a specialist nature and are excluded from the current SAICA tax syllabus: for example retirement funds, farming activities, and mining. Flesher and Rescho (1986, p. 63) acknowledged that practitioners do not require the academic programme to provide knowledge of highly technical concepts, of a specialized nature.

Sixty two per cent (62\%) of the respondents indicated that the trainee accountants have negligible to no knowledge of general administration $(M=2.31)$, despite this topic's inclusion in the current SAICA tax syllabus. It is suggested that the current SAICA tax syllabus focuses on the legislation documenting administration and does not specifically deal with the practical application thereof (e.g. actual completion of various tax forms). Also of concern is the suggestion that $54 \%$ of the respondents are of the opinion that the trainee accountants have negligible to no knowledge of the taxation of employment companies $(M=2.28)$, which is included in the current SAICA tax syllabus.

Seventy per cent (70\%) of the respondents suggested that the trainee accountants have negligible to no tax knowledge of tax planning $(M<1.92)$. SAICA (2005) listed efficient tax planning as a topic that a chartered accountant should be able to perform. A respondent indicated that trainee accountants lack the ability to approach an unstructured tax problem and could only perform 
basic calculations without considering the broader tax environment.

Of those topics included in the current SAICA tax syllabus, the respondents considered the trainee accountants to have the least knowledge of international taxation $(M=1.45)$. This result is not unexpected considering that this topic has been included in the SAICA tax syllabus at a basic 'knowledge and comprehension' level rather than an 'integration' level.

\section{Comparison of Small, Medium and Large Firms}

The responses were analysed based on firm size to identify whether any differences between firms of differing sizes could be identified. A comparison of the mean scores for the individual topics by firm size (Table 3) suggests that small firms rated the knowledge levels more highly than medium firms which in turn rated the knowledge levels higher than large firms. The relative lower ranking of the topics by large firms suggests that larger firms experience these topics in more complex situations and require a greater depth of knowledge.

\section{Table 3. Practitioners' perceptions of knowledge of trainee accountants (most knowledgeable to least knowledgeable)}

\begin{tabular}{|c|c|c|c|}
\hline $\begin{array}{l}\text { Small practices } \\
(n=8)\end{array}$ & SD $\quad M \quad \begin{array}{c}\text { Medium practices } \\
(n=6)\end{array}$ & $\begin{array}{l}\text { Large practices } \\
\quad(n=4)\end{array}$ & SD $\mathbf{M}$ \\
\hline \multicolumn{4}{|c|}{$\begin{array}{l}1=\text { No knowledge; } 2=\text { negligible knowledge; } 3 \text { = general knowledge; } 4 \text { = working knowledge; } \\
5=\text { thorough knowledge. }\end{array}$} \\
\hline \multicolumn{4}{|c|}{$\mathrm{M}=$ mean; SD = standard deviation. } \\
\hline \multicolumn{4}{|c|}{ Topics included in the SAICA syllabus } \\
\hline $\begin{array}{l}\text { Computer } \\
\text { applications (e-filing, } \\
\text { word processor } \\
\text { spreadsheet, etc.) }\end{array}$ & $\begin{array}{l}\text { Individuals tax and } \\
0.894 .33 \text { (excluding capital } \\
\text { gains tax) }\end{array}$ & $\begin{array}{c}\text { Individuals tax } \\
0.823 .67 \text { (excluding capital } \\
\text { gains tax) }\end{array}$ & 0.823 .00 \\
\hline $\begin{array}{l}\text { econdary tax on } \\
\text { mpanies (STC) }\end{array}$ & 0.274 .00 Value added tax & $\begin{array}{c}\text { Company tax } \\
0.843 .50 \text { (excluding capital } \\
\text { gains tax) }\end{array}$ & 0.823 .00 \\
\hline Value added tax & $0.864 .00 \begin{array}{l}\text { Secondary tax on } \\
\text { companies (STC) }\end{array}$ & $0.553 .50 \begin{array}{l}\text { Secondary tax on } \\
\text { companies (STC) }\end{array}$ & 0.823 .00 \\
\hline $\begin{array}{l}\text { Individuals tax } \\
\text { (excluding capital } \\
\text { gains tax) }\end{array}$ & $\begin{array}{c}\text { Company tax } \\
0.48 \text { 3.67 (excluding capital } \\
\text { gains tax) }\end{array}$ & 0.82 3.33 Employees' tax & 0.823 .00 \\
\hline $\begin{array}{l}\text { Company tax } \\
\text { (excluding capital } \\
\text { gains tax) }\end{array}$ & 0.50 3.67 Capital gains tax & 0.82 3.33 Capital gains tax & 0.823 .00 \\
\hline Employees' tax & 0.523 .67 Employees & 0.413 .17 Value ac & 0.823 .00 \\
\hline Provisional tax & 0.653 .67 Fringe benefits & 0.75 3.17 Donations tax & 0.502 .75 \\
\hline ns tax & 0.503 .67 Estate duty & 0.713 .00 Fringe $b$ & 0.502 .75 \\
\hline Lump sum benefits & 0.663 .50 Lump sum benefits & 0.63 3.00 Provisional tax & 0.582 .50 \\
\hline
\end{tabular}




\begin{tabular}{|c|c|c|c|}
\hline $\begin{array}{l}\text { from pension, } \\
\text { provident and } \\
\text { retirement annuity } \\
\text { funds }\end{array}$ & $\begin{array}{l}\text { from pension, } \\
\text { provident and } \\
\text { retirement annuity } \\
\text { funds }\end{array}$ & & \\
\hline & $\begin{array}{l}\text { Taxation of small } \\
\text { business }\end{array}$ & $\begin{array}{l}\text { Taxation of small } \\
\text { business }\end{array}$ & \\
\hline Estate duty & $\begin{array}{l}0.713 .50 \text { corporations } \\
\text { (excluding capital } \\
\text { gains tax) }\end{array}$ & $\begin{array}{l}0.752 .83 \text { corporations } \\
\text { (excluding capital } \\
\text { gains tax) }\end{array}$ & 0.962 .25 \\
\hline $\begin{array}{l}\text { Taxation of small } \\
\text { business corporations } \\
\text { (excluding capital } \\
\text { gains tax) }\end{array}$ & $\begin{array}{l}\text { Taxation of trusts } \\
0.983 .33 \text { (excluding capital } \\
\text { gains tax) }\end{array}$ & $0.412 .83 \begin{array}{l}\text { Taxation of non- } \\
\text { resident branch }\end{array}$ & 0.822 .00 \\
\hline Fringe benefits & 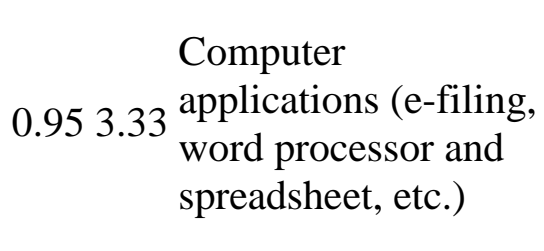 & $\begin{array}{l}\text { Lump sum benefits } \\
\text { from pension, } \\
0.842 .80 \text { provident and } \\
\text { retirement annuity } \\
\text { funds }\end{array}$ & 0.822 .00 \\
\hline $\begin{array}{l}\text { Taxation of trusts } \\
\text { (excluding capital } \\
\text { gains tax) }\end{array}$ & 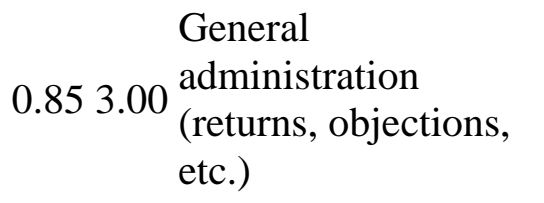 & $\begin{array}{l}\text { Taxation of trusts } \\
1.372 .67 \text { (excluding capital } \\
\text { gains tax) }\end{array}$ & 0.501 .75 \\
\hline Donations tax & 0.833 .00 Donations tax & 0.552 .60 Estate duty & 0.501 .75 \\
\hline $\begin{array}{l}\text { General } \\
\text { administration } \\
\text { (returns, objections, } \\
\text { etc.) }\end{array}$ & $\begin{array}{c}\text { Taxation of } \\
0.893 .00 \text { employment } \\
\text { companies }\end{array}$ & $\begin{array}{c}\text { Computer } \\
0.842 .50 \begin{array}{l}\text { applications (e-filing, } \\
\text { word processor and } \\
\text { spreadsheet, etc.) }\end{array}\end{array}$ & 0.961 .75 \\
\hline $\begin{array}{l}\text { Taxation of } \\
\text { employment } \\
\text { companies }\end{array}$ & 0.522 .50 Provisional tax & $\begin{array}{c}\text { Taxation of } \\
0.842 .50 \text { employment } \\
\text { companies }\end{array}$ & 1.151 .67 \\
\hline $\begin{array}{l}\text { Tax planning (the } \\
\text { structuring of, and } \\
\text { advice on, a client's } \\
\text { tax affairs, etc.) }\end{array}$ & $\begin{array}{c}\text { Tax planning (the } \\
\text { structuring of, and } \\
0.822 .00 \begin{array}{l}\text { advice on, a client's } \\
\text { tax affairs, etc.) }\end{array}\end{array}$ & $\begin{array}{c}\text { General } \\
1.142 .40 \begin{array}{l}\text { administration } \\
\text { (returns, objections, } \\
\text { etc.) }\end{array}\end{array}$ & 0.501 .25 \\
\hline $\begin{array}{l}\text { Taxation of non- } \\
\text { resident branch }\end{array}$ & $0.711 .00 \begin{array}{l}\text { Taxation of non- } \\
\text { resident branch }\end{array}$ & 0.842 .20 International tax & 0.501 .25 \\
\hline International tax & 0 International tax & $\begin{array}{l}\text { Tax planning (the } \\
\text { structuring of, and } \\
0.891 .60 \begin{array}{l}\text { advice on, a client's } \\
\text { tax affairs, etc.) }\end{array}\end{array}$ & 0.501 .25 \\
\hline \multicolumn{4}{|c|}{ Topics not included in the SAICA syllabus } \\
\hline $\begin{array}{l}\text { Taxation of farming } \\
\text { activities }\end{array}$ & $\begin{array}{c}\text { Taxation of public } \\
0.913 .50 \text { benefit organizations } \\
\text { (excluding capital }\end{array}$ & $\begin{array}{c}\text { Taxation of public } \\
0.842 .80 \text { benefit organizations } \\
\text { (excluding capital }\end{array}$ & 1.002 .00 \\
\hline
\end{tabular}




\begin{tabular}{|c|c|c|c|c|}
\hline & gains tax) & & gains tax) & \\
\hline $\begin{array}{l}\text { Taxation of long-term } \\
\text { insurers }\end{array}$ & $\begin{array}{c}\text { Tax research } \\
0.713 .00 \text { (researching case law } \\
\text { and legislation, etc.) }\end{array}$ & 1.102 .80 & $\begin{array}{l}\text { Taxation of } \\
\text { retirement funds }\end{array}$ & 1.002 .00 \\
\hline $\begin{array}{l}\text { Taxation of public } \\
\text { benefit organizations } \\
\text { (excluding capital } \\
\text { gains tax) }\end{array}$ & $\begin{array}{c}\text { Corporate rules } \\
1.033 .00 \text { (unbundling, } \\
\text { amalgamation, etc.) }\end{array}$ & 1.172 .17 & $\begin{array}{l}\text { Taxation of farming } \\
\text { activities }\end{array}$ & 0.501 .75 \\
\hline $\begin{array}{l}\text { Taxation of } \\
\text { retirement funds }\end{array}$ & $0.713 .00 \begin{array}{l}\text { Taxation of farming } \\
\text { activities }\end{array}$ & 0.712 .00 & $\begin{array}{l}\text { Transfer and stamp } \\
\text { duties }\end{array}$ & 0.501 .75 \\
\hline $\begin{array}{l}\text { Corporate rules } \\
\text { (unbundling, } \\
\text { Amalgamation, etc.) }\end{array}$ & $1.133 .00 \begin{array}{l}\text { Taxation of long- } \\
\text { term insurers }\end{array}$ & 1.412 .00 & $\begin{array}{l}\text { Tax research } \\
\text { (researching case law } \\
\text { and legislation, etc.) }\end{array}$ & 0.9 \\
\hline $\begin{array}{l}\text { Customs and excise } \\
\text { duties }\end{array}$ & $0.583 .00 \begin{array}{l}\text { Customs and excise } \\
\text { duties }\end{array}$ & 1.222 .00 & $\begin{array}{l}\text { Taxation of long- } \\
\text { term insurers }\end{array}$ & 1.151 .67 \\
\hline $\begin{array}{l}\text { Transfer and stamp } \\
\text { duties }\end{array}$ & $0.582 .50 \begin{array}{l}\text { Transfer and stamp } \\
\text { duties }\end{array}$ & 1.222 .00 & $\begin{array}{l}\text { Customs and excise } \\
\text { duties }\end{array}$ & 0.581 .50 \\
\hline
\end{tabular}

Tax research

(researching case law 0.512 .50 Taxation of mines and legislation, etc.)

1.791 .80 Taxation of mines $\quad 0.581 .33$

$\begin{array}{lccc}\text { Taxation of mines } & 0.391 .00 \begin{array}{l}\text { Taxation of } \\ \text { retirement funds }\end{array} & \begin{array}{c}\text { Corporate rules } \\ \text { (1.15 } 1.67 \text { (unbundling, } \\ \text { amalgamation, etc.) }\end{array} & 0.581 .33\end{array}$

Despite the non-inclusion of the taxation of farming in the current tax syllabus, small firms indicated that their trainee accountants have a general to working knowledge of this topic $(M=3.50)$. This may be indicative of the fact that this topic has until recently been included in the SAICA tax syllabus and certain accredited universities are still including the topic in their tax courses.

Tax planning is again of concern as all the respondent groups indicated that the trainee accountants' knowledge of this topic is leaning toward negligible or no tax knowledge $(M<2.5)$.

A Spearman rank order test was used to identify if any correlation existed in the ranking in Table 3 of the perception of knowledge by small, medium and large firms (Table 4). A high degree of positive correlation $\left(\mathrm{r}_{\mathrm{s}}>0.600\right)$ was identified and suggests that firms of varying sizes have similar perceptions of those topics in which the students are most knowledgeable.

Table 4. Spearman's rank order correlation of the perceptions of actual knowledge possessed

$\mathbf{r}_{\mathbf{s}}$

$r_{s}=$ Spearman's rank order correlation coefficient.

Small and medium practices 
Small and large practices

\section{Satisfaction with Performance of Their Duties by Entry-level Trainee Accountants}

Following the evaluation of respondents' perceptions of knowledge, the respondents were required to indicate their level of satisfaction with the performance of their duties by entry-level trainee accountants. The same tax topics that were identified for the evaluation of knowledge were listed in the questionnaire for the evaluation of satisfaction. The respondents were asked to measure their levels of satisfaction based on a five-point Likert scale (1 = very dissatisfied through to 5 = very satisfied).

Despite having general satisfaction with the tax knowledge of the trainee accountants, there is general dissatisfaction with the performance of their duties by the trainee accountants. When asked to evaluate their satisfaction with the trainee accountants' performance for tax in general, only 33\% $(n=6)$ of the respondents believe that the entry-level trainee accountants perform satisfactorily.

In order to identify specific tax topics that the respondents were not satisfied with, a mean score was calculated for each topic (Table 5). The respondents appear indifferent (neither satisfied nor dissatisfied) or dissatisfied $(M<3)$ with the trainee accountants' performance of their duties in respect of 20 of the 28 (71\%) tax topics in Table 5. These findings are, to an extent, understandable when one considers that 9 of these 20 topics $(M<3)$ are not included in the current SAICA tax syllabus.

Table 5. Practitioners' satisfaction with the performance of their duties by entry-level trainee accountants $(n=18)$

$$
\begin{array}{cccccccc}
\text { n/a } & 1 & 2 & 3 & 4 & 5 & \text { SD } & \text { M } \\
\% & \% & \% & \% & \% & \% & &
\end{array}
$$

1 = Very dissatisfied; 2 = dissatisfied; 3 = neither dissatisfied or satisfied; 4 = satisfied;

5 = very satisfied.

$\mathrm{n} / \mathrm{a}=$ Not applicable to respondent as they do not have clients to which the topic is applicable.

$\mathrm{M}=$ mean, $\mathrm{SD}=$ standard deviation.

Topics included in SAICA syllabus

Secondary tax on companies (STC)

Individuals tax (excluding capital gains tax)

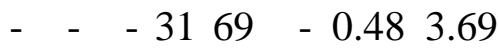

Value added tax

- $\quad$ - 23393180.933 .24

Company tax (excluding capital gains tax)

Fringe benefits

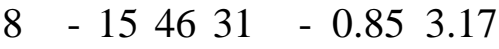

Employees' tax

- $\quad-233939-0.803 .16$

Capital gains tax

- $\quad-233939-0.803 .16$

- $\quad 313139-0.863 .08$

- $\quad-234631-0.763 .08$ 
Donations tax

Provisional tax

Computer applications (e-filing, word processor and spreadsheet, etc.)

Estate duty

Lump sum benefits from pension, provident and retirement annuity funds

International tax

Taxation of small business corporations (excluding capital gains tax)

Taxation of non-resident branch

Taxation of employment companies

Tax planning (the structuring of, and advice on, a client's tax affairs, etc.)

General administration (returns, objections, etc.)

Taxation of trusts (excluding capital gains tax)

Topics not included in SAICA syllabus

Tax research (researching case law and legislation, etc.)

Taxation of retirement funds

Customs and excise duties

Taxation of farming activities

Taxation of public benefit organizations (excluding capital gains tax)

Transfer and stamp duties

Taxation of long-term insurers

Taxation of mines

Corporate rules (unbundling, amalgamation, etc.)

$$
\begin{aligned}
& 8 \quad-1561 \quad 15-0.603 .00 \\
& \text { - } \quad \text { - } 393131 \quad-0.862 .92
\end{aligned}
$$

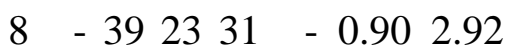

$$
\begin{aligned}
& \begin{array}{llllll}
23 & -23 & 23 & 15 & -0.74 & 2.90
\end{array} \\
& \begin{array}{lllllll}
8 & 8 & 23 & 39 & 23 & -0.94 & 2.84
\end{array}
\end{aligned}
$$

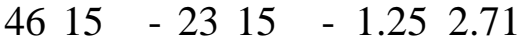

$$
\begin{aligned}
& \text { - } \quad \text { - } 463915 \quad-0.752 .69 \\
& \begin{array}{llllllll}
31 & 8 & 23 & 31 & 8 & -0.88 & 2.56
\end{array} \\
& \begin{array}{llllllll}
15 & 8 & 31 & 39 & 8 & - & 0.82 & 2.55
\end{array} \\
& \begin{array}{lllllll}
8 & -54 & 31 & 8 & -0.67 & 2.50
\end{array} \\
& \text { - } \quad \text { - } 61318 \text { - } 0.662 .46 \\
& \text { - } 23313115-1.042 .38 \\
& 15 \quad-234615 \quad-0.702 .91
\end{aligned}
$$

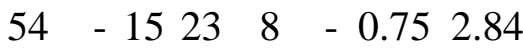

$$
\begin{aligned}
& \begin{array}{llllllll}
23 & 8 & 23 & 39 & 8 & - & 0.84 & 2.61
\end{array} \\
& \begin{array}{lllllll}
23 & 8 & 31 & 23 & 15 & -0.97 & 2.60
\end{array} \\
& \begin{array}{llllllll}
23 & 8 & 31 & 31 & 8 & - & 0.85 & 2.50
\end{array} \\
& \begin{array}{llllllll}
23 & 8 & 31 & 31 & 8 & -0.85 & 2.50
\end{array}
\end{aligned}
$$

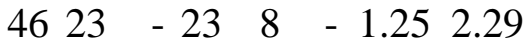

$$
\begin{aligned}
& \begin{array}{llllllll}
46 & 23 & 8 & 15 & 8 & -1.21 & 2.15
\end{array} \\
& 152354 \quad-\quad 8 \quad-0.831 .91
\end{aligned}
$$

Of the 11 topics actually included in the current SAICA tax syllabus $54 \%$ of the practitioners' were dissatisfied with the trainee accountants' performance in respect of the taxation of trusts ( $M=2.38)$, 61\% were dissatisfied with general administration $(M=2.46)$ and $54 \%$ were dissatisfied with tax planning $(M=2.50)$. Tax planning and general administration also scored poorly in the evaluation of the respondents' perception of the trainee accountants' knowledge. It is suggested that respondents, therefore, evaluate the knowledge of these practical topics based on the trainee accountants being able to perform in the practice environment.

A concern might be that the respondents may be confusing the skill of 'being able to' in the practical environment with the 'knowing how' component of knowledge acquired during the formal academic programme. Having the knowledge how to do or to perform something does not mean having the skill to perform in the practice environment (Jarvis, 1983). Schwartz and Stout (1987, p. 121) indicated that practitioners considered practical methods of education to be important and it is suggested that the respondents are expecting a greater transfer of skills in the 
academic environment. The use of case studies was encouraged in this regard by a respondent. It is suggested that it needs to be resolved as to what extent, if any, practical experience, the 'being able to', can be acquired in the academic environment. To facilitate this resolution the partnership in tax education needs to strengthen between practitioners and educators (Rubin, 1999, p. 808).

\section{Comparison of Small, Medium and Large Firms}

A comparison of the satisfaction levels between firms of differing sizes is provided in Table 6 by ranking the topics based on their mean scores. A Spearman's rank order test was used to identify any correlation in the level of satisfaction between small, medium and large firms. The correlation coefficients (Table 7) indicate a medium degree of positive correlation $\left(\mathrm{r}_{\mathrm{s}}>0.400\right)$ between small firms and medium or large firms and a higher degree of positive correlation $\left(r_{s}>0.600\right)$ between the medium and large firms. Although these correlations exist between firms, small firms expressed satisfaction (based on $M>3$ ) with a greater number of topics (15) than the medium and large firms (nine each). This suggests that the larger the firm, the greater the expectation.

\section{Table 6. Practitioners' satisfaction with the performance of their duties by entry-level trainee accountants (Most satisfied to least satisfied)}

$$
\begin{aligned}
& \text { Small practices } \\
& (n=8) \\
& \text { SD M Medium practices } \\
& (\boldsymbol{n}=6) \\
& (n=4)
\end{aligned}
$$

Topics Included in the SAICA syllabus

Computer

applications (e-filing, word processor and spreadsheet, etc.)

Secondary tax on companies (STC)

Company tax (excluding capital gains tax)

Employees' tax

Fringe benefits

Individuals tax (excluding capital gains tax)

Estate duty $0.544 .00 \begin{aligned} & \text { Secondary tax on } \\ & \text { companies (STC) }\end{aligned}$

0.15 4.00 Value added tax

$0.543 .67 \begin{aligned} & \text { Taxation of } \\ & \text { retirement funds }\end{aligned}$

$0.563 .67 \begin{aligned} & \text { Taxation of non- } \\ & \text { resident branch }\end{aligned}$

0.54 3.67 International tax Individuals tax

0.523 .67 (excluding capital gains tax)

Lump sum benefits

0.613 .50 from pension, provident and
$0.553 .50 \begin{aligned} & \text { Secondary tax on } \\ & \text { companies (STC) }\end{aligned}$

0.503 .75

Company tax

0.753 .17 (excluding capital gains tax)

1.41 3.01 Employees' tax

0.963 .25

0.82 3.00 Provisional tax

0.963 .25

1.41 3.00 Capital gains tax

0.963 .25

0.89 3.00 Value added tax

0.963 .25

Individuals tax

0.893 .00 (excluding capital gains tax) 
retirement annuity

funds

$\begin{array}{lr}\text { Capital gains tax } & \begin{array}{r}0.49 \\ \text { B.33 Fringe benefi } \\ \text { Donations tax }\end{array} \\ \begin{array}{l}\text { Company tax } \\ \text { (excluding ca }\end{array} \\ \begin{array}{l}\text { Taxation of trusts } \\ \text { gaxcluding capital } \\ \text { gains tax) }\end{array} & \begin{array}{c}\text { Taxation of } \\ \text { employment } \\ \text { companies }\end{array}\end{array}$

Provisional tax

Value added tax

General

administration

(returns, objections, etc.)

Tax planning (the structuring of, and advice on, a client's tax affairs, etc.)

Lump sum benefits from pension, provident and retirement annuity funds

Taxation of small business corporations (excluding capital gains tax)

Taxation of employment companies

Taxation of nonresident branch

International tax gains tax)
0.96 3.33 Donations tax Computer 0.482 .67 applications (e-filing spreadsheet, etc.)
0.89 3.00 Donations tax 03.00

0.752 .83 Fringe benefits

0.823 .00

Taxation of small

$0.752 .83 \begin{aligned} & \text { business corporations } \\ & \text { (excluding capital }\end{aligned}$ gains tax)

Lump sum benefits from pension,

$$
\text { 0.51 3.33 Capital gains tax }
$$

0.752 .83 provident and retirement annuity funds

0.842 .80 Estate duty

Taxation of

0.842 .80 employment companies

$$
0.962 .75 \begin{aligned}
& \text { Taxation of non- } \\
& \text { resident branch }
\end{aligned}
$$

General

0.54 2.50 Employees' tax

Tax planning (the 0.502 .00 structuring of, and advice on, a client's tax affairs, etc.) Taxation of small $0.781 .50 \begin{aligned} & \text { business corporations } \\ & \text { (excluding capital }\end{aligned}$
$0.752 .67 \begin{aligned} & \text { administration } \\ & \text { (returns, objections, }\end{aligned}$ etc.)

Tax planning (the

$0.892 .60 \begin{aligned} & \text { structuring of, and } \\ & \text { advice on, a client's }\end{aligned} \quad 0.502 .25$ tax affairs, etc.)

Taxation of trusts

0.842 .50 (excluding capital $\quad 0.501 .75$ gains tax)

0.842 .50 International tax

1.151 .67

1.10 1.00 Provisional tax

Taxation of trusts $0 \quad 0$ (excluding capital gains tax)
Computer

1.212 .33 applications (e-filing, word processor and spreadsheet, etc.) 
Topics not included in the SAICA syllabus

\begin{tabular}{|c|c|c|c|}
\hline $\begin{array}{l}\text { Taxation of farming } \\
\text { activities }\end{array}$ & $\begin{array}{c}\text { Tax research } \\
0.723 .50 \text { (researching case law } \\
\text { and legislation, etc.) }\end{array}$ & $\begin{array}{c}\text { Tax research } \\
0.843 .20 \text { (researching case law } \\
\text { and legislation, etc.) }\end{array}$ & 0.502 .75 \\
\hline $\begin{array}{l}\text { Customs and excise } \\
\text { duties }\end{array}$ & $0.233 .00 \begin{array}{l}\text { Taxation of } \\
\text { retirement funds }\end{array}$ & $1.413 .01 \begin{array}{l}\text { Taxation of } \\
\text { retirement funds }\end{array}$ & 0.582 .67 \\
\hline $\begin{array}{l}\text { Taxation of } \\
\text { retirement funds }\end{array}$ & 0.123 .00 Taxation of mines & $1.532 .67 \begin{array}{l}\text { Customs and excise } \\
\text { duties }\end{array}$ & 0.582 .50 \\
\hline $\begin{array}{l}\text { Taxation of public } \\
\text { benefit organizations } \\
\text { (excluding capital } \\
\text { gains tax) }\end{array}$ & $0.502 .50 \begin{array}{l}\text { Taxation of long- } \\
\text { term insurers }\end{array}$ & $1.532 .67 \begin{array}{l}\text { Transfer and stamp } \\
\text { duties }\end{array}$ & 0.582 .50 \\
\hline $\begin{array}{l}\text { Tax research } \\
\text { (researching case law } \\
\text { and legislation etc.) }\end{array}$ & $\begin{array}{l}\text { Taxation of public } \\
0.552 .50 \begin{array}{l}\text { benefit organizations } \\
\text { (excluding capital } \\
\text { gains tax) }\end{array}\end{array}$ & $0.892 .60 \begin{array}{l}\text { Taxation of long- } \\
\text { term insurers }\end{array}$ & 1.152 .33 \\
\hline $\begin{array}{l}\text { Transfer and stamp } \\
\text { duties }\end{array}$ & $0.502 .50 \begin{array}{l}\text { Customs and excise } \\
\text { duties }\end{array}$ & $\begin{aligned} \text { Taxation of public } \\
\text { benefit organizations } \\
\text { (excluding capital } \\
\text { gains tax) }\end{aligned}$ & 1.152 .33 \\
\hline $\begin{array}{l}\text { Corporate rules } \\
\text { (unbundling, } \\
\text { amalgamation, etc.) }\end{array}$ & $0.052 .00 \begin{array}{l}\text { Transfer and stamp } \\
\text { duties }\end{array}$ & $1.292 .50 \begin{array}{l}\text { Taxation of farming } \\
\text { activities }\end{array}$ & 1.152 .33 \\
\hline Taxation of mines & $0.811 .00 \begin{array}{l}\text { Taxation of farming } \\
\text { activities }\end{array}$ & 0.892 .40 Taxation of mines & 1.002 .00 \\
\hline $\begin{array}{l}\text { Taxation of long- } \\
\text { term insurers }\end{array}$ & $\begin{array}{c}\text { Corporate rules } \\
0.911 .00 \text { (unbundling, } \\
\text { amalgamation, etc.) }\end{array}$ & $\begin{array}{c}\text { Corporate rules } \\
1.12 .00 \text { (unbundling, } \\
\text { amalgamation, etc.) }\end{array}$ & 0.581 .67 \\
\hline
\end{tabular}

Table 7. Spearman's rank order correlation of satisfaction with the performance of their duties by entry-level trainee accountants

$\mathbf{r}_{\mathbf{s}}$

$r_{s}=$ Spearman's rank order correlation coefficient.

Small and medium practices $\quad 0.579$

$\begin{array}{ll}\text { Small and large practices } & 0.553\end{array}$

$\begin{array}{lr}\text { Medium and large practices } & 0.618\end{array}$

\section{Conclusion}

The SAICA syllabus committee is responsible for developing the tax syllabus that must be completed by a trainee accountant at a SAICA-accredited university prior to entering the training environment in South Africa. The success of this syllabus is measured largely by the pass rates in the final qualifying examinations (Botha, 2001, p. 42). Local literature (Botha and de Jager, 
2001) has identified that the education system may not necessarily be delivering competent chartered accountants. In addition, foreign literature (Boley and Wilkie, 1986, Flescher and Rescho, 1986, Miller and Woods, 2000, Schwartz and Stout, 1987, and Stara et al., 1991) has identified that the education programmes are not adequately meeting the needs of practitioners. These findings, supplemented by the lack of reported studies on tax education in South Africa, prompted this descriptive exploratory study to identify practitioners':

i. perceptions of the existing tax knowledge of trainee accountants entering the training environment in public practice; and

ii. satisfaction with the performance of their duties by the trainee accountants based on their existing knowledge.

This study is an attempt to document the current tax education environment and evaluate the success thereof. It is suggested that for the most part the respondents are of the opinion that the knowledge levels of 'entry-level' trainee accountants are adequate. However, there appears to be room for improvement as far as the practical application of such knowledge is concerned. These findings are similar to those of Miller and Woods (2000) who commented that students do not seem to be able to transfer their abilities in the academic environment to the work place.

The results suggest that the practitioners' perceptions in South Africa mirror those of the practitioners in the USA and the UK as they are placing more emphasis on performing computations and completing tax forms. This is, however, in contrast to the situation in New Zealand where it has been suggested that the focus ought to be on more conceptual understanding than technical proficiency (Tan and Veal, 2005).

To bridge the divide more effectively between the transfer of knowledge and acquisition of skills, tax educators in South Africa may need to review the practicality of the current tax education programme. For this purpose Schwartz and Stout (1987) suggested that academics make more extensive use of materials such as practice sets, case studies and tax forms in the classroom. Deciding which of these methods to employ in any given circumstances is not necessarily easy and trade offs between the methods may have to be made (Hite and Hasseldine, 2001, p. 11).

It is acknowledged that care needs to be taken to ensure that training officers do not simply delegate their educational and mentoring responsibilities to the academics. Schwartz and Stout (1987) noted that it is important that academics acknowledge the practitioners' requests and it is just as important that the practitioners better understand why the curriculum is as it is. Further research in this regard is encouraged. Finally, the syllabus setter (SAICA) should continually review the content of the tax syllabus to assist in the development of competent chartered accountants.

While it appears that in future the taxation component of professional accounting programmes should be leaning towards a more vocational nature, consideration needs to be given to the comment made by Miller and Woods (2000) that universities should implement both vocational and non-vocational programmes. The dilemma in South Africa in this regard is the careeroriented requirements of the NQF and the associated demise of non-vocational programmes. 
Further research in this regard is required.

The limited empirical data precludes generalisation of the study's findings. This study was primarily exploratory and descriptive in nature and additional research is needed into the research objectives. In order to obtain a broader and more balanced view of this research area in South Africa, further research of the perceptions of additional stakeholders in the tax education environment (including educators, alumni and students) is required. In addition further research of academics' and practitioners' understanding of the 'knowing how' component of knowledge and skills is encouraged. Such research may assist in confirming if there is a misunderstanding of these terms amongst practitioners and educators and whether each party clearly understands their respective responsibilities in the education and training of aspirant chartered accountants.

\section{References}

1. Boley, R. and Wilkie, P. (1986) Practitioners' view of the common body of tax knowledge for persons entering public accounting. Journal of the American Taxation Association 8:1 , pp. 80-97.

2. Botha, W. J. J. (2001) Pre-qualification education of registered accountants and auditors in South Africa: perspectives on whether the education process is normatively justifiable. Meditari 9:1 , pp. 34-59.

3. Botha, W. J. J. and de Jager, H. (2001) Perspectives of the education requirements for Registered Accountants and Auditors in South Africa. University of Pretoria School of Accountancy and the Pretoria Association of Chartered Accountants Research Report No. 24 UP Printers , Pretoria

4. Coetzee, Q. (June 2006) TOPP works for us. Accountancy SA pp. $42-43$

5. Cooper, M. P. , Blair, J. and Triplet, T. (1999) A comparison of mail and e-mail for a survey of employees in U.S. statistical agencies. Journal of Official Statistics 15:1, pp. 39-56. 6.

6. Craner, J. and Lymer, A. (1999) Tax education in the UK: a survey of tax courses in undergraduate accounting degrees. Accounting Education: an international journal_ 8:2 , pp. 127-156.

7. Dayasena, M. (2003) South Africa: a positive outlook. International Accounting Bulletin 21:3 , pp. 11-15.

8. Department of Education (1995) White paper on Education and Training Department of Education , Pretoria

9. Ensor, P. (2003) The national qualification framework and higher education in South Africa: some epistemological issues. Journal of Education and Work_16:3 , pp. 325-346. 
10. Flesher, T. K. and Rescho, J. A. (1986) Tax concepts and their importance in the undergraduate curriculum. Journal of Accounting Education 4:1 , pp. 55-68.

11. Fogg, S. L. and Campbell, J. D. (1982) The teaching of taxation in schools of business administration. The Ohio CPA Journal 41:1 , pp. 57-59.

12. Gray, O. L. (1965) Opinions of tax professors on tax courses: a survey summary. The Accounting Review 40:1 , pp. 204-211.

13. Hite, P. and Hasseldine, J. (2001) A primer on tax education in the United States of America. Accounting Education: an international journal_10:1 , pp. 3-13.

14. Jarvis, P. (1983) Professional education Croom Helm Limited , Beckenham

15. Miller, A. M. and Woods, C. M. (2000) Undergraduate tax education: a comparison of educators' and employers' perceptions in the UK. Accounting Education: an international journal 9:3 , pp. 223-241.

16. Mouton, J. (2001) How to succeed with your masters and doctoral studies: a South African guide and resource book Van Schaik Publishers, Pretoria

17. Mulder, C. (August 2000) Are accounting education and educators boring?. Accountancy SA p. 1.

18. Niewoudt, M. and Wilcocks, J. S. (2005) The attitudes and perceptions of South African accounting academics about research. Meditari 13:2 , pp. 49-66.

19. O'Neil, C. J. (1999) Assessing the impact of the AICPA model tax curriculum on the first tax course taught at AACSB-Accredited Institutions. The Tax Advisor 30:8 , pp. 596600.

20. Oppenheimer, J. S. (1997) The Model Tax Curriculum-Tax Education for the 21st century. The Tax Advisor 25:5 , pp. 322-323.

21. Rubin, J. T. (1999) Tax practitioners response to education survey. The Tax Advisor 30:11 , pp. 806-808.

22. Schnee, E. J. (2002) Evaluating tax education: a survey of new hires. The Tax Advisor 33:8 , pp. 540-542. [

23. Schwartz, B. N. and Stout, D. E. (1987) A comparison of practitioner and educator opinions on tax education requirements for undergraduate accounting majors. Issues in Accounting Education 2:1, pp. 112-126.

24. South African Institute of Chartered Accountants (2003) Education requirements for entry into part 1 of the qualifying examination. - Available at http://www.saica.co.za 
(accessed 1 December 2005)

25. South African Institute of Chartered Accountants (2005) What AAT's, AGA's, and CA's do - Available at http://www.saica.co.za (accessed 30 November 2005)

26. South African Institute of Chartered Accountants (2006a) Training general information. - Available at http://www.saica.co.za (accessed 6 May 2006)

27. South African Institute of Chartered Accountants (2006b) What CA's do. Available at http://www.saica.co.za (accessed 1 June 2006)

28. South African Institute of Chartered Accountants (2006c) TIPP. — Available at http://www.saica.co.za (accessed 5 May 2006)

29. South African Institute of Chartered Accountants (2006d) Education Committee Terms of Reference. — Available at http://www.saica.co.za (accessed 19 April 2007)

30. South African Institute of Chartered Accountants (2007) Independent research reveals CA(SA) is, overwhelming, SA's most sought-after business designation. - Available at http://www.saica.co.za (accessed 1 May 2007)

31. South African Revenue Service (2002) Regulating tax practitioners: Discussion paper Government Printer , Pretoria

32. Stara, N. , Shoemaker, P. and Brown, J. (1991) The curriculum required to develop a tax specialist: a comparison of practitioner opinions with current programs. Journal of Accounting Education 9:1, pp. 79-104.

33. Stroker, D. J. (1981) Steekproefneming in die praktyk. Prof Honorer Lesing, UP Nuwe Reeks, Nr 178. (Sampling in practice. Prof Honoury Lecture, UP New Series, No. 178) UP Printers , Pretoria

34. Tan, L. T. and Veal, J. (2005) Tax knowledge for undergraduate accounting majors: conceptual v. technical. eJournal of Tax Research - Available at http://0www.atax.unsw.edu.au.innopac.up.ac.za/ejtr/ (accessed 8 April 2007)

35. Tshwane (2007) Business prospects and investment - Available at http://www.tshwane.gov (accessed 2 April 2007) 